\title{
Response of Sheep Fed on Corn Cob Silage or Elephant Grass Basal Diet with or without Calliandra Leaf Meal Supplementation
}

\author{
Yulistiani D \\ Indonesian Research Institue of Animal Production, Bogor \\ e-mail:dwiyulistiani@yahoo.com
}

(received 19-07-2016; revised 08-09-2016; accepted 13-09-2016)

\begin{abstract}
ABSTRAK
Yulistiani D. 2016. Respon domba yang diberi pakan dasar silase tongkol jagung atau rumput gajah dengan atau tanpa suplementasi Kaliandra. JITV 21(3): 165-173. DOI: http://dx.doi.org/10.14334/jitv.v21i3.1574

Terbatasnya ketersediaan hijauan pakan sepanjang tahun dapat diatasi melalui penggunaan hasil samping pertanian. Tongkol jagung, hasil samping produksi jagung potensial untuk digunakan sebagai sumber serat pengganti rumput. Tujuan dari penelitian ini untuk membandingkan pengaruh dua jenis pakan dasar (rumput dan silase tongkol jagung) dengan dan tanpa suplementasi tepung daun kaliandra terhadap konsumsi, kecernaan pakan, penggunaan nitrogen, fermentasi rumen dan pertumbuhan domba. Penelitian menggunakan 20 ekor anak domba St Croix jantan lepas sapih. Domba dikelompok menjadi 5 kelompok berdasarkan bobot badan. Tiap ekor domba dalam tiap kelompok diberikan salah satu dari 4 pakan perlakuan selama 13 minggu. Pakan perlakuan yang diberikan adalah: pakan dasar rumput + konsentrat, pakan dasar silase tongkol jagung (CCS) + konsentrat, pakan dasar rumput + konsentrat $+5 \%$ tepung daun kaliandra, CCS + konsentrat $+5 \%$ tepung daun kaliandra. Imbangan pakan dasar (rumput atau silase tongkol jagung) dengan konsentrat adalah $40: 60 \%$ dan diformulasikan secara iso-protein (kandungan protein kasar 14\%) pakan diberikan secara total mixed ration. Penelitian dilakukan menggunakan rancangan acak kelompok pola faktorial 2x2 (2 tipe pakan dasar dan 2 level suplementasi kaliandra) dengan 5 ulangan. Hasil penelitian menunjukkan tidak ada interaksi antara pakan dasar dan suplementasi kaliandara terhadap konsumsi pakan, pertambahan bobot badan, kecernaan pakan dan fermentasi rumen, kecuali pada konsumsi protein kasar. Konsumsi pakan tidak dipengaruhi oleh pakan dasar dan suplementasi kaliandra. Ratio konversi pakan dan ratio konversi protein lebih baik pada pakan dasar rumput dibanding silase tongkol jagung. Kecernaan protein kasar di pakan dasar silase tongkol jagung lebih tinggi dibanding pakan dasar rumput yang tanpa diberi suplementasi tepung daun kaliandra. Retensi nitrogen lebih tinggi di pakan dasar CCS dibanding pakan dasar rumput. Fermentasi rumen dipengaruhi oleh jenis pakan dasar dimana konsentrasi rumen ammonia, total VFA dan proporsi propionat lebih tinggi pada pakan dasar rumput. Dari penelitian ini dapat disimpulkan bahwa pada pakan iso protein pakan dasar rumput sebanding dengan pakan dasar silase tongkol jagung seperti yang ditunjukkan dengan pertambahan bobot badan harian yang sama (107,5 g/ekor/hari) pada kedua jenis pakan tersebut. Suplementasi tepung dau kaliandra pada level 5\% tidak meningkatkan tampilan domba.
\end{abstract}

Kata Kunci: Tongkol Jagung, Kaliandra, Domba, Rumput Gajah

\begin{abstract}
Yulistiani D. 2016. Response of sheep fed on corn cob silage or elephant grass basal diet with or without Calliandra leaf meal supplementation. JITV 21(3): 165-173. DOI: http://dx.doi.org/10.14334/jitv.v21i3.1574

Limited availability of forage diet throughout the year could be overcome by utilization of crop by-products. Corn cob, a byproduct from maize production is potential to be used as a fiber source for grass replacement. The objective of the study was to compare the effect of two different basal diets (basal grass diet and corn cob silage) with or without Calliandra supplementation on feed intake, nutrient digestibility, nitrogen utilization, rumen fermentation and growth of sheep. The study used 20 male sheep St Croix breed. The sheep were divided into 5 groups based on body weight. Each group was fed with one of four diet treatments for 13 weeks. The treatments were grass basal diet + concentrate, Corn cob silage (CCS) + concentrate, Grass basal diet + concentrate $+5 \%$ Calliandra leaf meal, CCS + concentrate $+5 \%$ Calliandra leaf meal. The ratio of basal diet (grass or CCS) to concentrate was $40: 60 \%$ and was formulated in iso protein (crude protein content 14\%). The diet was offered in total mix ration. The experiment was conducted in a randomized complete block design and arranged in factorial $2 \times 2$ ( 2 type basal diets and 2 Calliandra supplementation levels) with 5 replications. Results showed that there was no interaction between basal diet and Calliandra supplementation on feed consumption, average daily gain (ADG), nutrient digestibility, rumen fermentation, except for crude protein (CP) intake. Feed consumption was not affected by basal diets or Calliandra supplementation. Feed conversion ratio and protein conversion ratio were better in grass basal diet than CCS. CP digestibility was higher in corn cob silage than basal grass diet without Calliandra supplementation. $\mathrm{N}$ retention was higher in corn cob basal diet than basal grass diet. Rumen fermentation was significantly affected by basal diet in which rumen ammonia and VFA concentrations were higher in grass basal diet. Grass basal diet had higher propionic acid production than CCS basal diet. From this study, it could be concluded that in iso protein diet, basal grass diet was comparable to corn cob basal diet as revealed by average daily gain was similar in both diets with average $107.5 \mathrm{~g} / \mathrm{head} /$ day. Calliandra supplementation at $5 \%$ in the grass or CCS basal diet did not improve sheep performance.
\end{abstract}

Key Words: Corn Cob, Silage, Calliandra, Sheep, Elephant Grass 


\section{INTRODUCTION}

The productivity of ruminants in Indonesia is constrained by the shortage of feed availability either in quantity or quality, particularly in a dry season when the availability of forage is limited. This condition becomes critical due to the priority of land use is for food crop planting as well as the conversion of grazing area for settlement and infrastructure. Limited availability of forage diet could be overcome by utilization of crop by-products. One of the potential crop by products is a by-product from corn production. Corn is one of food crops targeted by Indonesian Government to be self-sufficient domestically. The increase of corn production will be followed by the increase in corn by-products, one of them is corn cob. Corn cob is potential to be used as a roughage source for grass replacement. Ground corn cob can be used as a basal diet for sheep up to $40 \%$ (Yulistiani \& Puastuti 2012). Wanapat et al. (2012) reported that ground corn cob was able to replace cassava chip in concentrate diet for swamp buffaloes, while Wachirapakorn et al. (2014) used corn cob mixed with rice straw as a roughage source in the total mixed ration for lactating dairy cow. Corn cob is not palatable and easily contaminated by fungi Aspergillus flavus which is very toxic to the animal. Ensiling is able to increase corn cob palatability as indicated by the high intake of corn cob silage (Yulistiani \& Puastuti 2012) and able to prevent fungal contamination.

High productivity state of ruminants animal (growth, pregnancy, lactation) their nutrient requirement are higher than for maintenance. Their Protein requirement can not be met from rumen microbial supply. Therefore, to achieve the optimal productivity ruminants must be offered diet containing rumen undegradable protein sources that are digestible (Mustafa et al. 2000; Saricicek 2000) such as legume forage containing tannin.

Calliandra is one of the legumes containing CT which is able to grow in infertile soil and can be used as bypass protein supplement. CT content in Calliandra tends to be higher in infertile soil. The range of CT content in Calliandra was 19.9-24.7\% (Tiemann et al. 2010). Besides its potential in supplying bypass protein, Calliandra was able to reduce enteric methane emission by $24 \%$ when non-tanniniferous legume was replaced by Calliandra at $30 \%$ (Tiemann et al. 2008).

Corn cob silage was potential to be used as a roughage source to replace a freshly chopped grass diet. However, its productivity was still lower than basal grass diet (Yulistiani \& Puastuti 2012). Therefore, an attempt should be made to increase sheep growth rate in corn cob basal diet by supplementing with by-pass protein. To the best of the author knowledge, no information is available on the Calliandra supplementation in corn cob silage basal diet for sheep. The objective of the study was to compare the effect of two different basal diets (basal grass diet and corn cob silage) with or without Calliandra supplementation on feed intake, nutrient digestibility, nitrogen utilization, rumen fermentation and growth of sheep.

\section{MATERIALS AND METHODS}

\section{Feeds, animal feeding, and experimental design}

Corn cob silage was prepared by mixing ground corn cob (90\% DM) and fine ground corn grain at $2 \%$ of corn cob (w/w). The mixture was then sprayed with water to obtain DM $40 \%$ and kept in air tight plastic bag for at least 21 days. After 21 days, the silage was ready to be used for sheep feeding.

Calliandra leaf meal was prepared by drying the Calliandra foliage under the sun for 3 days or until it was dry (DM 85\%), and ground using hammer mill with a sieving size of $5 \mathrm{~mm}$.

Animal management and feeding experiment: The study used 20 male St Croix sheep with an average initial body weight of $15.93 \pm 3.0 \mathrm{~kg}$. In growth trial, sheep were kept in an individual pen for 12 weeks (including 1 week adaptation period) and fed on a diet mixture of chopped elephant grass (Pennisetum purpureum) or corn cob silage with concentrate. The diet was given in total mix ration. The ratio of basal diet (grass or corn cob silage) with concentrate was 40: $60 \%$. The ration was formulated in iso-nitrogenous (CP $14 \%)$. Diets were fed twice daily in equal portion (09.00 am and $15.00 \mathrm{pm})$. The nutrient content of the feed used in the study is presented in Table 1. The sheep were divided into 5 groups based on body weight, where each lamb in each group was fed on one of four dietary treatments. The dietary treatments were as follows:

1. Elephant Grass + Concentrate

2. Elephant Grass + Concentrate $+5 \%$ Calliandra leaf meal.

3. Corn cob silage + Concentrate

4. Corn cob silage + Concentrate $+5 \%$ Calliandara leaf meal.

Before the study, sheep were dewormed using commercial de-wormer (valbazen). For estimating nutrient digestibility at the end of growth trial, sheep 
Table 1. Chemical composition of the feeds used in experimental diet

\begin{tabular}{lcccc}
\hline \hline \multirow{2}{*}{ Parameter } & \multicolumn{4}{c}{ Chemical composition (\% DM) } \\
\cline { 2 - 5 } & OM & CP & NDF & ADF \\
\hline Elephant grass & 87.5 & 6.5 & 68.3 & 48.6 \\
Corn cob silage & 96.6 & 3.5 & 75.7 & 42.7 \\
Concentrate for grass based diet mixture & 92.5 & 19 & 21.7 & 9.09 \\
Concentrate for corn cob silage based diet & 91.9 & 22 & 14.9 & 9.74 \\
mixture & & & 52.4 & 41.29 \\
Calliandra leaf meal & 82.8 & 14.5 & 5 & \\
\hline
\end{tabular}

$\mathrm{OM}$, organic matter; $\mathrm{CP}$, crude protein; NDF, neutral detergent fibre, ADF, acid detergent fiber.

were moved to metabolism cages for 2 weeks: comprising of a week each for adaptation and collection periods.

The experiment was conducted in a randomized complete block design and arranged in factorial $2 \times 2$ consisted of 2 different basal diets of elephant grass and corn cob silage and that 2 supplementation levels with or without Calliandra. Calliandra leaf meal (5\%) was added to the ration.

\section{Parameters recorded}

Parameters recorded were feed consumption, growth rate, nutrient digestibility, feed efficiency, $\mathrm{N}$ balance and rumen characteristics. Feed consumption was measured daily by calculating the difference between feed offered and refused.

Daily feed offered was weighed, and refusal was also weighed in the morning before the feed was given. Feed digestibility was measured using total collection method by daily weighing feed offered, refusal and fecal excreted for 7 days. For measuring nitrogen $(\mathrm{N})$ balance, $\mathrm{N}$ in the feed, feces and in urine was analyzed. Urine production was measured daily: urine was collected in a bucket containing $5 \mathrm{ml}$ concentrated $\mathrm{H}_{2} \mathrm{SO}_{4}$. Feces, feed offered, and refusal was subsampled $(100 \mathrm{~g})$ and dried in an oven for 7 days. Samples from each animal in each day were taken $10 \%$ and bulked for each animal and ground for chemical analysis. After 8 days of the collection period, rumen fluid of each sheep was collected using a stomach tube. Rumen fluid was collected at 3 hours after morning feed. Rumen fluid was analyzed for $\mathrm{pH}$ and ammonia $\left(\mathrm{NH}_{3}-\mathrm{N}\right)$ and VFA concentration. Growth rates of sheep were obtained by bi-weekly weighing in the morning before feeding. Nitrogen balance was measured by calculating the difference between $\mathrm{N}$ intake and $\mathrm{N}$ in urine and feces.

\section{Sample analysis}

Crude protein, dry matter, organic matter analyses were done according to the method of AOAC (1990), while NDF and ADF analyses were carried out according to the method of Van Soest et al. (1991). Rumen ammonia was analyzed using Conway's method, while VFA was analyzed using gas chromatography.

\section{Statistical analysis}

Data were analyzed using ANOVA of SAS program 9.1 (SAS 2004) and that differences among means were compared using Duncan's multiple range test. All the differences were stated at $5 \%$.

\section{RESULTS AND DISCUSSION}

DM, CP intake, average daily gain (ADG) and feed conversion are shown in Table 2. There was no interaction effect of basal diet and Calliandra supplementation or main effect of basal diet and supplementation on feed consumption (DMI and CP intake), ADG and feed conversion. The average DMI intake of all treatment was $3.89 \%$. This level of DM intake was higher than the level suggested by (Kearl 1982) for sheep or NRC (2007) for growing male sheep. The consumption of corn cob silage basal diet in the current study was similar to the previous study reported by Yulistiani \& Puastuti (2012). 
Table 2. Feed consumption and performance of lamb fed on different feeding treatments

\begin{tabular}{|c|c|c|c|c|c|c|c|}
\hline \multirow{3}{*}{ Variables } & \multicolumn{4}{|c|}{ Main Factor } & & & \\
\hline & \multicolumn{2}{|c|}{ Basal diet (B) } & \multicolumn{2}{|c|}{$\begin{array}{l}\text { Supplement } \\
(\%, S)\end{array}$} & \multicolumn{3}{|c|}{$P$ values } \\
\hline & Grass & $\mathrm{CCS}$ & 0 & 5 & B & $S$ & $\mathrm{~B} \times \mathrm{S}$ \\
\hline \multicolumn{8}{|l|}{ Dry matter intake } \\
\hline Total DMI (g/head/day) & 759 & 773 & 748 & 784 & 0.6367 & 0.4974 & 0.4901 \\
\hline DMI g/kg BW & 37.6 & 39.3 & 37.6 & 39.3 & 0.3721 & 0.6272 & 0.8872 \\
\hline DMI/ BW 0,75 & 79.3 & 82.5 & 79.0 & 82.7 & 0.3424 & 0.5326 & 0.8311 \\
\hline$\% \mathrm{DMI} / \mathrm{BW}$ & 4.03 & 3.76 & 3.75 & 3.93 & 0.3716 & 0.6286 & 0.8887 \\
\hline CP intake (g/head/day) & 121.2 & 135.5 & 126.2 & 130.5 & 0.1963 & 0.6962 & 0.3797 \\
\hline $\mathrm{CP}$ intake $\mathrm{g} / \mathrm{kg} \mathrm{BW}$ & $6.06^{\mathrm{b}}$ & $6.83 \mathrm{a}$ & 6.34 & 6.55 & $<0.0001$ & 0.0872 & 0.0272 \\
\hline ADG (g/head/day) & 111.5 & 104.2 & 103.2 & 113.2 & 0.3588 & 0.2034 & 0.7635 \\
\hline Feed conversion ratio & $6.85^{\mathrm{a}}$ & $8.20^{\mathrm{b}}$ & 7.71 & 7.31 & 0.0233 & 0.4898 & 0.3210 \\
\hline Protein conversion ratio & $1.09^{\mathrm{b}}$ & $1.44^{\mathrm{a}}$ & 1.32 & 1.22 & 0.0022 & 0.3049 & 0.1149 \\
\hline
\end{tabular}

Different letter in one row indicated significant different $(\mathrm{P}<0.05)$; CCS, corn cob silage; DMI, dry matter intake; CP crude protein; ADG, average daily gain.

Intake of $\mathrm{CP}$ was significantly $(\mathrm{P}<0.05)$ affected by the interaction of basal diet and Calliandra supplementation. Calliandra supplementation was able to increase CP intake in a grass basal diet. Calliandra supplementation was not able to increase $\mathrm{CP}$ intake in the CCS basal diet, due to the CP content (14.5\%) of Calliandra used in the current study was low status. The low protein content of Calliandra used in present study was relatively to a very mature and mixed with stem during pruning. Hence, supplementation of $5 \%$ Calliandra did not increase the $\mathrm{CP}$ content of the diet. Acero-Camelo et al. (2009) also reported low CP content of Calliandra (14.3\%). The CP content of Calliandra decreased with increasing plant maturity from $21 \%$ at 6 weeks to $18 \%$ at 12 weeks cutting intervals (Abqoriyah et al. 2015) and from 23.2 to $15.6 \%$ from six to 16 weeks cutting intervals (Kabi \& Bareeba 2008).

The ADG in all treatments was similar in a current experiment with average $107.8 \mathrm{~g} / \mathrm{head} /$ day. Kearl (1982) recommended that the $\mathrm{CP}$ required by sheep with a body weight of $15 \mathrm{~kg}$ getting a daily body gain of $100 \mathrm{~g} /$ day was estimated to be $100 \mathrm{~g} \mathrm{CP} /$ day and digestible intake protein (DIP) of $80 \mathrm{~g} /$ day. NRC suggested that lower amount of digestible protein intake (100 g LW/day) was required for growth which was 70 $\mathrm{g} /$ day. The average DIP in the present study was 84.5 , 109.7, 97.0 and $95.3 \mathrm{~g}$ /day respectively for grass, corn cob, 0 and 5\% Calliandra supplementation. Those values of DIP intake in the present study were higher than suggested by Kearl (1982) and NRC (2007). In this study, only grass basal diet showed similar DIP intake to Kearl (1982) recommendation and the ADG obtained was $111.5 \mathrm{~g} / \mathrm{head} / \mathrm{day}$. The ADG obtained in the present study was higher than previously reported for sheep fed on CCS and grass basal diets of Sumatera Cross Bred sheep having ADG of 59.4 in CCS diet and 80.3 $\mathrm{g} /$ head/day in grass basal diet (Yulistiani \& Puastuti 2012). This differences could be associated with the breed of sheep in the study. Results of previous study (Yulistiani et al. 2015) with similar breed of sheep (St Croix) showed DMI (3.7\% BW) and CP intake (4.5 $\mathrm{g} / \mathrm{kg} \mathrm{BW}$ ) were lower and resulted low in ADG (72.8 g/day) compared to the current study ADG (107.5 $\mathrm{g} /$ day). The higher nutrient intake of the present research resulted in better performance of sheep than the previous study.

No response to Calliandra supplementation on goat growth rate was also reported by Acero-Camelo et al. (2009), where the supplementation of $20 \%$ fresh Calliandra leaves did not significantly increase the body weight of goat grazed on native grass pastures (Dichanthiumannulatum, Heteropoguncontortus, Cynodondactylon).

Feed conversion ratio and protein conversion ratio were affected by the type of basal diets. The feed conversion and protein conversion ratio of grass basal diet is better $(\mathrm{P}<0.05)$ than CCS basal diet. Although the ADG and feed consumption were not affected $(\mathrm{P}>0.05)$ by treatments, feed conversion ratio, and protein conversion ratio was better in grass basal diet 
Table 3. Nutrient digestibility of sheep fed on different diet treatments

\begin{tabular}{|c|c|c|c|c|c|c|c|}
\hline \multirow{3}{*}{ Variables } & \multicolumn{4}{|c|}{ Main Factor } & & & \\
\hline & \multicolumn{2}{|c|}{ Basal diet (B) } & \multicolumn{2}{|c|}{$\begin{array}{l}\text { Supplement } \\
(\%, S)\end{array}$} & \multicolumn{3}{|c|}{$P$ values } \\
\hline & Grass & CCS & 0 & 5 & B & $S$ & $B \times S$ \\
\hline Dry matter & 62.0 & 64.1 & 63.7 & 62.1 & 0.2843 & 0.4091 & 0.7902 \\
\hline Organic matter & 67.1 & 68.9 & 70.4 & 65.7 & 0.4599 & 0.0636 & 0.2784 \\
\hline Crude protein & $69.7 b$ & $81.0 \mathrm{a}$ & $77.4 \mathrm{x}$ & $73.3 y$ & 0.0001 & 0.0094 & 0.1800 \\
\hline Neutral detergent fiber & 49.4 & 55.8 & 54.4 & 51.1 & 0.0686 & 0.1988 & 0.8067 \\
\hline Acid detergent fiber & 49.5 & 54.9 & 55.6 & 50.2 & 0.2370 & 0.2764 & 0.6990 \\
\hline
\end{tabular}

Different letter in one row indicated significant different $(\mathrm{P}<0.05)$; CCS, corn cob silage

Table 4. Nitrogen (N) utilization in sheep fed on different diet treatments

\begin{tabular}{|c|c|c|c|c|c|c|c|}
\hline \multirow{3}{*}{ Variables } & \multicolumn{4}{|c|}{ Main Factor } & & & \\
\hline & \multicolumn{2}{|c|}{ Basal diet (B) } & \multicolumn{2}{|c|}{$\begin{array}{l}\text { Supplement } \\
(\%, S)\end{array}$} & \multicolumn{3}{|c|}{$\mathrm{P}$ values } \\
\hline & Grass & $\mathrm{CCS}$ & 0 & 5 & B & S & B x S \\
\hline $\mathrm{N}$ intake $(\mathrm{g})$ & $18.91 \mathrm{~b}$ & $23.0 \mathrm{a}$ & 20.93 & 20.98 & 0.0003 & 0.9527 & 0.3200 \\
\hline $\mathrm{N}$ feses $(\mathrm{g})$ & $5.75 \mathrm{a}$ & $4.35 \mathrm{~b}$ & $4.57 \mathrm{x}$ & $5.52 \mathrm{~b}$ & 0.0050 & 0.0382 & 0.5246 \\
\hline $\mathrm{N}$ urine $(\mathrm{g})$ & 5.31 & 5.37 & 5.31 & 5.37 & 0.8736 & 0.8283 & 0.5187 \\
\hline $\mathrm{N}$ absorbtion $(\mathrm{g})$ & $13.16 \mathrm{~b}$ & $18.64 \mathrm{a}$ & 16.35 & 15.45 & 0.0001 & 0.1395 & 0.0795 \\
\hline $\mathrm{N}$ retention $(\mathrm{g})$ & $7.85 b$ & $13.2 \mathrm{a}$ & 11.0 & 10.1 & 0.0001 & 0.1242 & 0.0634 \\
\hline$\% \mathrm{~N}$ feses/ intake & $30.30 \mathrm{a}$ & $19.0 \mathrm{~b}$ & $22.6 x$ & $26.6 y$ & 0.0001 & 0.0094 & 0.1800 \\
\hline$\% \mathrm{~N}$ urine/ intake & $28.1 \mathrm{a}$ & $23.3 \mathrm{~b}$ & 25.3 & 25.6 & 0.0437 & 0.9726 & 0.2192 \\
\hline$\% \mathrm{~N}$ absorbn/intake & $69.7 \mathrm{~b}$ & $81.0 \mathrm{a}$ & $77.4 \mathrm{x}$ & $73.3 y$ & 0.0001 & 0.0094 & 0.1800 \\
\hline$\% \mathrm{~N}$ retention/ intake & $41.5 \mathrm{~b}$ & $57.7 \mathrm{a}$ & $52.8 \mathrm{x}$ & $48.1 \mathrm{y}$ & 0.0001 & 0.0219 & 0.1626 \\
\hline
\end{tabular}

Different letter in one row indicated significantly different $(\mathrm{P}<0.05)$; CCS, corn cob silage

than CCS basal diet. This is attributed by feed conversion ratio, and protein conversion ratio which was calculated from feed intake (DMI and CPI) divided by ADG. Therefore, the higher ADG and lower DMI and CPI in grass basal diet resulted in better feed conversion ratio and protein conversion ratio. This indicates that basal grass diet was more efficient than CCS basal diet.

Nutrient digestibility in sheep fed on diet treatment shows DM, OM, NDF, ADF, and CP was not affected by either interaction of basal diet and Calliandra supplementation or by the main effect of basal diet and supplementation, except for $\mathrm{CP}$ (Table 3). CP digestibility was affected by the type of basal diets and levels of Calliandra supplementation. CP digestibility of corn cob basal diet was higher than grass basal diet. Lima et al. (2011) reported that CP digestibility of sorghum silage was higher than the fresh sorghum forage.

CP digestibility with Calliandra was lower than without supplementation. This lower CP digestibility in Calliandra supplemented diet could be related to tannin content in Calliandra. The presence of condensed tannin (CT) in the feed formed CT-protein complexes during mastication which is resistant to degradation in the rumen (Makkar 2003).This CT-protein complexes pass through the rumen and then partially broken down in the abomasums and duodenum at $\mathrm{pH} 2-3$ resulted in higher fecal $\mathrm{N}$ (Tiemann et al. 2008). In the case of tannin in Calliandra, it was reported that its proteintannin complex had the lowest digestibility from abomasums through feces than other legumes (Leucaena $\mathrm{sp}$ ) (Kariuki \& Norton 2008). This resulted 
in the higher $\mathrm{N}$ content in feces or lower $\mathrm{CP}$ digestibility of Calliandra supplemented the diet.

Nitrogen (N) utilization of sheep fed on diet treatments showed $\mathrm{N}$ use was not affected by the interaction between type of basal diet and Calliandra supplementation (Table 4). All $\mathrm{N}$ utilization parameters recorded (in g/day) were affected by the type of basal diets except for $\mathrm{N}$ excreted through urine. However, when the parameter was expressed in percentage of $\mathrm{N}$ intake, all the parameters were affected $(\mathrm{P}<0.05)$ by basal diets and supplement. $\mathrm{N}$ intake in CCS basal diet was higher than in grass basal diet $(\mathrm{P}<0.05)$. However, $\mathrm{N}$ excretion in feces of grass basal diet was higher than in CCS basal diet. The higher $\mathrm{N}$ excretion of grass basal diet could be due to $\mathrm{N}$ bound to undigested cell wall fiber is excreted through feces. CP content in the grass is higher than CCS (Table 1) in which partly bound to the cell wall. $\mathrm{N}$ retention of CCS basal diet was higher than grass basal diet. This result indicates that CCS basal diet is better than grass basal diet.

Fecal $\mathrm{N}$ in Calliandra supplemented diet was higher than unsupplemented diet (Table 4). The increased of fecal $\mathrm{N}$ in Calliandra supplementation diet indicates that tannin-protein complex could be incompletely digested in the lower digestive tract, the increase of $\mathrm{N}$ feses was about $25 \%$ compared to unsupplemented diet. Result in the present study was supported by the result of Kai et al. (2016) who reported that the increased level of tannic acid supplementation caused in increased $\mathrm{N}$ excretion in feces by $25.3 \%$ at level supplementation tannic acid 2.6\% in the diet. Moreover, Kai et al. (2016) reported that tannic acid supplementation caused shifting $\mathrm{N}$ excretion from urine to feces. Therefore, they found no difference in $\mathrm{N}$ retention between with or without tannic acid supplementation. In the present study, $\mathrm{N}$ retention was significantly higher in a diet without Calliandra supplementation. The nonsignificant differences of $\mathrm{N}$ excretion between supplemented and unsupplemented diet in the urine indicated that protein degradation of both diets was similar. It seems that supplementation of Calliandra which is expected to play an important role in protecting protein and supplying by pass protein did not occur, even more protein was excreted in the feces there by tannin protein complex in Calliandra which was not dissociated in the abomasum and lower digestive tract. It was also shown that the un-supplemented diet had $10 \%$ higher $\mathrm{N}$ retention. Katuromunda et al. (2012) also reported that elephant grass diet supplemented by Calliandra excreted more $\mathrm{N}$ in feces compared to control or to Centrosema or Desmodium. Further, Korrir et al. (2016) reported although Calliandra supplementation to wheat straw diet increased $\mathrm{N}$ retention, but fecal $\mathrm{N}$ excretion was also high.

Rumen fermentation in sheep fed on diet treatments showed there is no interaction effect of type basal diet and Calliandra supplementation on rumen fermentation (Table 5). Rumen $\mathrm{pH}$ was similar in all diet treatments with an average of 6.56. This $\mathrm{pH}$ was in the range (6.57.0) of ideal condition for microbial activities in the rumen for fiber and protein digestion (Wanapat \& Cherdthong 2009; Calabro et al. 2008). Oelker et al. (2009) also reported similar ruminal $\mathrm{pH}$ of cows fed on

Table 5. Average of ruminal $\mathrm{pH}$, ammonia nitrogen $(\mathrm{NH} 3-\mathrm{N})$ and VFA concentration in the rumen fluid of lamb fed on diet treatments

\begin{tabular}{|c|c|c|c|c|c|c|c|}
\hline \multirow{3}{*}{ Variables } & \multicolumn{4}{|c|}{ Main Factor } & & & \\
\hline & \multicolumn{2}{|c|}{$\begin{array}{l}\text { Basal diet } \\
\text { (B) }\end{array}$} & \multicolumn{2}{|c|}{$\begin{array}{l}\text { Supplement } \\
(\%, \mathrm{~S})\end{array}$} & \multicolumn{3}{|c|}{$\mathrm{P}$ values } \\
\hline & Grass & $\mathrm{CCS}$ & 0 & 5 & B & S & $\mathrm{B} \times \mathrm{S}$ \\
\hline Rumen $\mathrm{pH}$ & 6.59 & 6.53 & 6.50 & 6.62 & 0.4805 & 0.1757 & 0.8599 \\
\hline $\begin{array}{l}\text { Rumen NH3-N } \\
(\mathrm{mg} / 100 \mathrm{ml})\end{array}$ & $15.4 \mathrm{a}$ & $9.8 b$ & 11.6 & 12.6 & 0.0008 & 0.4125 & 1.000 \\
\hline Total VFA mMol & $127.8 \mathrm{a}$ & $104.8 \mathrm{~b}$ & 120.0 & 112.2 & 0.0001 & 0.1740 & 0.2553 \\
\hline \multicolumn{8}{|l|}{ Proportion VFA (\%) } \\
\hline Acetate & $63.5 b$ & $68.2 \mathrm{a}$ & 66.3 & 65.3 & 0.0082 & 0.5060 & 0.8637 \\
\hline Propionate & $26.4 \mathrm{a}$ & $20.9 b$ & 23.2 & 24.0 & 0.0048 & 0.6367 & 0.8718 \\
\hline Butyrate & 10.01 & 8.74 & 9.14 & 9.61 & 0.1320 & 0.5661 & 0.3892 \\
\hline Others VFA & $1.34 \mathrm{a}$ & $0.93 b$ & 1.25 & 1.02 & 0.047 & 0.2324 & 0.3406 \\
\hline Ratio acetat/propionat & $2.46 b$ & $3.30 \mathrm{a}$ & 2.94 & 2.81 & 0.0024 & 0.5488 & 0.9717 \\
\hline
\end{tabular}

Different letter in one row indicated significantly different $(\mathrm{P}<0.05)$; CCS, corn cob silage; VFA, volatile fatty acid. 
corn silage or chopped alfalfa hay. Rumen ammonia $\left(\mathrm{NH}_{3}-\mathrm{N}\right)$ was significantly higher in grass basal diet than the CCS diet. Feed protein in the rumen degraded into an amino acid, $\mathrm{NH}_{3}-\mathrm{N}$ formed in the rumen from amino acid breakdown. The excess of $\mathrm{NH}_{3}-\mathrm{N}$ which is not incorporated during microbial synthesis is absorbed from the rumen and converted into urea in the liver and excreted in the urine (Patra \& Saxena 2011). The high $\mathrm{NH}_{3}-\mathrm{N}$ in grass basal diet was due to feeding fresh forages, its protein became rapidly soluble during mastication, releasing $56-65 \%$ of protein concentration as a soluble protein in the rumen. This soluble protein degraded in the rumen and resulted in the increased rumen $\mathrm{NH}_{3}-\mathrm{N}$ concentration (Ullyatt et al. 1975).

The similarity in rumen $\mathrm{NH}_{3}-\mathrm{N}$ concentration between un-supplemented and Calliandra supplemented diets indicates that protein in Calliandra was not degraded in the rumen which was caused by a tanninprotein complex that resistant to microbial degradation in the rumen (Makkar 2003). It is generally agreed that tannin in feed reduced the rate of protein degradation in the rumen. The reduction of protein degradation could lower NH3-N level in the rumen (Patra \& Saxena 2011). The average concentration of rumen $\mathrm{NH}_{3}-\mathrm{N}$ in this study for un-supplemented and Calliandra supplemented diets was $12.1 \mathrm{mg} / \mathrm{dl}$. The optimum concentration of $\mathrm{NH}_{3}-\mathrm{N}$ suggested by Satter \& Slyter (1974) was $5 \mathrm{mg} \mathrm{NH}_{3}-\mathrm{N} / \mathrm{dl}$ for rumen microbial synthesis, but higher values $(10-20 \mathrm{mg} / 100 \mathrm{ml})$ had also been recommended (Preston \& Leng 1987) to optimize degradation of fibrous feed. It seems that the rumen $\mathrm{NH}_{3}-\mathrm{N}$ concentration in this study in all treatment diets was in the ideal conditions for optimizing grass or CCS basal diet. Therefore, all diet treatments had similar fiber digestibility (Table 2).

Total volatile fatty acid (VFA) production was significantly $(\mathrm{P}<0.05)$ affected by the type of basal diets (Table 5). However, Calliandra supplementation did not significantly affect total VFA production and molar proportion of VFA. Similarly, Tiemann et al. (2008) also observed that substitution of none-tanniniferous legume (Vigna) with tannin-rich legumes Calliandra or Flemingia did not change total VFA and proportion of VFA

Total VFA production in grass basal diet was higher by $21 \%$ compared to CCS diet. The higher total VFA production was followed by the higher propionate proportion in this diet consequently the acetic to propionic acid ratio decreased. In contrast to the present study, Lima et al. (2011) reported that feeding sorghum and soybean forage mixture silage produced a higher propionic acid than fresh forage. The higher propionic acid in silage diet was due to the lactic acid formation during ensiling was converted to propionic acid in the rumen. Lactic acid originated from the fermentation of water soluble carbohydrate (McDonald et al. 2002). In the current study, CCS diet produced higher acetic acid proportion, which was related to corn cob containing high fiber (NDF content $75.7 \%$, Table 1). The higher NDF content of CCS produced a higher proportion of acetic acid.

In the current study, grass basal diet was more efficient either in FCR or in crude protein conversion ratio. In fact, the net protein utilization (Nretained/ $\mathrm{N}$ intake) or protein biological value $(\mathrm{N}$ retention/ $\mathrm{N}$ absorption) was higher in the CCS basal diet. However, this diet was less efficient compared to a basal grass diet. Biological value is the proportion of feed protein utilized by the animal for synthesizing body tissues and compounds (McDonald et al. 2002). Animals have low ability to store amino acid in a free state when the amino acid is not required for protein synthesis it will be broken down used as an energy source. The higher total VFA production might be matched with protein availability, consequently feed conversion ratio, and protein conversion ratio in grass basal diet was better than CCS diet. More over higher production of propionic acid which is a precursor for meat production in grass basal diet caused better performance sheep in grass diet. Although ADG and feed consumption were not significantly different between treatments, the grass basal diet was more efficient than CCS diet as indicated by better feed conversion ratio and protein conversion ratio (Table 2).

In the case of Calliandra supplementation, it was expected to be able to supply bypass protein due to its tannin content protecting protein of feed from rumen microbial degradation thereby more protein was available to be absorbed in the intestine and used for building body tissue, which in turn increased lamb growth rate. However, in the present study Calliandra supplementation was not able to improve lambs growth rate as indicated the similarity of ADG in the unsupplemented diet. Although the supplemented diet protein did not degrade in the rumen, the Calliandra protein diet supplementation was excreted in feces. This could be the reason for no performance improvement of lambs fed on supplemented by $5 \%$ Calliandra leaf meal.

\section{CONCLUSION}

Corn cob silage could be used as an alternative roughage source, especially in a dry season to replace grass basal diet, since the body weight gain was similar between grass basal diet and corn cob silage diet in isoprotein diet for sheep. In addition, corn cob silage is also better in $\mathrm{CP}$ and $\mathrm{N}$ utilization. Five percents supplementation of Calliandra in the diet was not improved sheep performance significantly. 


\section{ACKNOWLEDGMENTS}

The authors would like to thank the Indonesian Agency of Agricultural Research and Development, Ministry of Agriculture, Indonesia, for financial support. We thank to Dr. Wisri Puastuti for her advice during experiment and Technician in IRIAP Research Station in Bogor for their assistance in conducting experiment.

\section{REFERENCES}

Abqoriyah, Utomo R, Suwignyo B. 2015. Produktivitas tanaman kaliandra (Calliandra calothyrsus) sebagai hijauan pakan pada umur pemotongan yang berbeda. Buletin Peternakan. 39:103-108.

Acero-Camelo A, Valencia E, Rodriguez AA, Randel PF. 2009. Calliandra calothyrsus supplementation effects on weight gain and efficacy of control of gastrointestinal nematodes in weanling goats. J Agr Univ P R. 93:51-60.

[AOAC] Association of Official Analytical Chemist. 1990. Official Method of Analysis. 12th ed. Washington DC (USA): Association of Official Analytical Chemist

Calabrò S, Moniello G, Piccolo C, Bovera F, Infascelli F, Tudisco R, Cutrignelli MI. 2008. Rumen fermentation and degradability in buffalo and cattle using the in vitro gas production technique. J Anim Physiol Anim Nutr. 92:356-362.

Kabi F, Bareeba FB. 2008. Herbage biomass production and nutritive value of mulberry (Morus alba) and Calliandra calothyrsus harvested at different cutting frequencies. Anim Feed Sci Technol. 140:178-190.

Kai Y, Wei C, Zhao G, Xu Z, Lin S. 2016. Dietary supplementation of tannic acid modulates nitrogen excretion pattern and urinary nitrogenous constituents of beef cattle. Livest Sci. 191:148-152.

Kariuki IW, Norton BW. 2008. The digestion of dietary protein bound by condensed tannins in the gastrointestinaltract of sheep. Anim Feed Sci Technol. 142:197-209.

Katuromunda S, Sabiiti EN, Mateete-Bekunda A. 2012. Effect of legume foliage supplementary feeding to dairy cattle offered Pennisetum purpureum basal diet on feed intake and manure quality. Uganda J Agric Sci, 2012. 13:2534.

Kearl LC. 1982. Nutrient requirements of ruminants in developing countries. Utah (USA): International Feedstuff Institute. Utah Agricultural Experiment Station. Utah State University.

Korrir D, Goopy JP, Gachuiri C, Butterbach-Bahl K. 2016. Supplementation with Calliandra calothyrsus improves nitrogen retention in cattle fed low-protein diets. Anim Prod Sci. 56:619-626.
Lima R, Díaz RF, Castro A, Fievez V. 2011. Digestibility, methane production and nitrogen balance in sheep fed ensiled or fresh mixtures of sorghum-soybean forage. Livest Sci. 141:36-46.

Makkar HPS. 2003. Effects and fate of tannins in ruminant animals, adaptation to tannins, and strategies to overcome detrimental effects of feeding tannin-rich feeds. Small Rumin Res. 49:241-256. doi: 10.1016/S0921-4488(03)00142.

McDonald P, Edwards RA, Greenhalgh JFD, Morgan CA. 2002. Animal Nutrition. 6th editions. United Kingdom: Harlow, Pearson Education Limited.

Mustafa AF, McKinnon JJ, Christensen DA. 2000. Protection of canola meal and seed protein from ruminal degradation. Asian-Aust J Anim Sci. 13:535-542.

[NRC] National Research Council. 2007. Nutrient Requirement of Small Ruminants. Washington DC (USA): National Academic Press.

Oelker ER, Reveneau C, Firkins JL. 2009. Interaction of molasses and monensin in alfalfa hay- or corn silagebased diets on rumen fermentation, total tract digestibility, and milk production by Holstein cows. J Dairy Sci. 92:270-285.

Preston TR, Leng RA. 1987. Matching ruminant production systems with available resources in the tropics and subtropics. New South Wales (Australia): Penambul Books, Armidale.

Saricicek BZ. 2000. Protected (by-pass) protein and feed value of hazelnut kernel oil meal. AJAS. 1:317-322.

SAS Institute. 2004. SAS User's guide. Version 9.1 . SAS Institute.Inc.. Cary. NC.

Satter LD, Slyter LL. 1974. Effect of ammonia concentration on rumen microbial protein production in vitro. $\mathrm{Br} \mathrm{J}$ Nutr. 32:199-208.

Tiemann TT, Lascano CE, Wettstein HR, Mayer AC, Kreuzer M, Hess HD. 2008. Effect of the tropical tannin-rich shrub legumes Calliandra calothyrsus and Flemingia macrophylla on methane emission and nitrogen and energy balance in growing lambs sheep. Animal. 2:790799.

Tiemann TT, Franco LH, Ramirez G, Kreuzer M, Lascano CE, Hess HD. 2010. Influence of cultivation site and fertilisation on the properties of condensed tannins and in vitro ruminal nutrient degradation of Calliandra calothyrsus, Flemingia macrophylla and Leucaena leucocephala. Anim Feed Sci Technol. 157:30-40.

Patra AK, Saxena J. 2011. Exploitation of dietary tannins to improve rumen metabolism and ruminant nutrition. $\mathbf{J}$ Sci Food Agric. 91:24-37. doi: 10.1002/jsfa.4152.

Ulyatt MJ, McRae JC, Clarke TJ, Pearce PD. 1975. Quantitative digestion bof fresh forages by sheep. 4. Protein synthesis in the stomach. J Agric Sci (Camb) 84:453-458.

Van Soest PJ, Robertson JB, Lewis BA. 1991. Methods for dietary fiber neutral detergent fiber and non-starch 
polysaccharides in relation to animal nutrition. J Dairy Sci. 74:3583-3597.

Wachirapakorn C, Parmaluk P, Wanapat M, Pakdee P, Cherdthong A. 2014. Effects of levels of crude protein and ground corn cobs in total mixed ration on intake, rumen fermentation and milk production in crossbred Holstein Friesian lactating dairy cows. J App Anim Res. 42:263-268. doi: 10.1080/09712119.2013.842483.

Wanapat M, Cherdthong A. 2009. Use of real-time PCR technique in studying rumen cellulolytic bacteria population as affected by level of roughage in swamp buffalo. Curr Microbiol. 58:294-299.

Wanapat M, Pilajun R, Kang S, Setyaningsih K, Setyawan AR. 2012. Effect of ground corn cob replacement for cassava chip on feed intake, rumen fermentation and urinary derivatives in Swamp buffaloes. AJAS. 25:1124-1131.

Yulistiani D, Puastuti W. 2012. Feed consumption and growth response of lambs fed on different basal diet. In: Koonawootrittriron S, Suwanasupee T, Jaichansukkit T, Jattawa D, Boonyanuwat K, Skunmun P, editors. Proceedings of the 15th AAAP Animal Science Congress. Bangkok (Thailand): Thammasat University, Rangsit Campus. p. 733-736.

Yulistiani D, Naufaliah N, Kardaya D, Subandriyo. 2015. Nutrient digestibility and growth of five breeds of sheep under different levels of undegradable protein. JITV. 20:23-30. doi: 10.14334/jitv.v20i1.1112. 